Review

\title{
Timing of Initiation of Renal Replacement Therapy in Sepsis-Associated Acute Kidney Injury
}

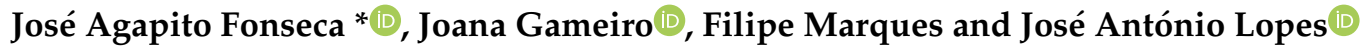 \\ Division of Nephrology and Renal Transplantation, Department of Medicine Centro Hospitalar Lisboa Norte, \\ EPE Av. Prof. Egas Moniz, 1649-035 Lisboa, Portugal; joana.estrelagameiro@gmail.com (J.G.); \\ filipedcmarques@campus.ul.pt (F.M.); jalopes93@hotmail.com (J.A.L.) \\ * Correspondence: jose.nuno.agapito@gmail.com
}

Received: 20 April 2020; Accepted: 7 May 2020; Published: 10 May 2020

\begin{abstract}
Sepsis-associated acute kidney injury (SA-AKI) is a major issue in medical, surgical and intensive care settings and is an independent risk factor for increased mortality, as well as hospital length of stay and cost. SA-AKI encompasses a proper pathophysiology where renal and systemic inflammation play an essential role, surpassing the classic concept of acute tubular necrosis. No specific treatment has been defined yet, and renal replacement therapy (RRT) remains the cornerstone supportive therapy for the most severe cases. The timing to start RRT, however, remains controversial, with early and late strategies providing conflicting results. This article provides a comprehensive review on the available evidence on the timing to start RRT in patients with SA-AKI.
\end{abstract}

Keywords: acute kidney injury; prevention; renal replacement therapy; sepsis; treatment

\section{Introduction}

Acute kidney injury (AKI) is a clinical syndrome characterized by a rapid decline in kidney function, encompassing numerous etiologies, and different and complex pathophysiological processes [1,2]. AKI is particularly important since it is strongly associated with increased hospital length of stay (LOS), costs, in-hospital mortality, development of chronic kidney disease (CKD) and long-term mortality risk [3-6]. The global burden of AKI accounts for around 13.3 million cases a year, and in the United States alone hospitalizations for AKI are on the rise [7-9].

The definition of AKI has undergone serious modifications over the last twenty years. Since the first consensual definition provided in 2004 by the Risk, Injury, Failure, Loss of kidney function and End-stage renal disease (RIFLE) classification [10], the initial term of acute renal failure (ARF) evolved to AKI as small increases in serum creatinine ( $\mathrm{SCr}$ ) were associated with increased mortality $[1,11]$, widening the spectrum of the definition which now comprises from minor changes in markers of renal function to requirement for renal replacement therapy (RRT), as adopted by the Acute Kidney Injury Network (AKIN), in 2007 [12]. More recently, in 2012, the Kidney Disease: Improving Global Outcomes (KDIGO) combined both RIFLE and AKIN classifications, allowing for a definition that could be applied in clinical medicine, research and for public health purposes (Table 1) [13]. These definitions are not immutable and new definitions, chiefly concerning the duration of AKI, have recently been addressed, as observed by the proposed definitions for transient and persistent acute kidney disease (AKD) [14]. 
Table 1. Acute kidney injury according to the Kidney Disease: Improving Global Outcomes (KDIGO) classification. SCr-serum creatinine, $\mathrm{UO}$ - urinary output.

\begin{tabular}{ccc}
\hline \multicolumn{3}{c}{ Acute Kidney Injury Staging According to Kidney Disease Improving Global Outcomes } \\
(KDIGO) Classification
\end{tabular}

Acute complications related to AKI are diverse and depend on the severity of the insult [15]. Prompt recognition and early intervention directed to the cause of AKI and to the related complications, may soften both the duration and severity of this clinical syndrome, improving outcomes [16]. Special attention must be paid to identifying and eliminating potential insults, namely drugs, hypotensive states and exposure to iodinated contrast agents. Adequate volume assessment, as well as acid-based and electrolyte disturbances management must be addressed as well [17-20]. Nutritional support, surveillance of uremic symptoms and uremic bleeding associated with platelet dysfunction are also of critical importance in the management of AKI and the respective outcomes [21,22]. However, to date, no specific pharmacological therapy has proved to be effective in the prevention or treatment of AKI, partly owing to the various insults and different pathophysiological pathways associated with AKI [23].

In recent years, retrospective and prospective studies, as well as randomized controlled trials (RCTs), have focused on the timing of initiation of renal replacement therapy (RRT), yielding inconsistent results [24-27]. Most studies are considerably heterogenic concerning the definitions of early and late strategies. The clinical setting of the population is also highly variable between studies [28,29]. Whether an early, compared to a delayed strategy, for RRT initiation can improve outcomes in AKI is still a matter of debate.

Sepsis is the leading cause of AKI in critically ill patients, and sepsis-associated AKI (SA-AKI) is associated with higher severity scores, an increased need for RRT, and increases the risk of death and prolonged LOS compared to nonseptic AKI [30,31]. SA-AKI has a proper pathophysiology that exceeds the previously admitted acute tubular necrosis resulting from kidney ischemic injury. It is now understood that a set of different mechanisms including intra-renal and systemic inflammation, oxidative stress, microvascular and endothelial dysfunction are detrimental in the pathophysiology of SA-AKI [32-34].

Data regarding the impact of the timing of RRT initiation in SA-AKI are scarce and somewhat contradictory and inconclusive. In fact, most of the studies on this topic are small, retrospective, single-center and observational, and in studies addressing the impact of the timing of RRT initiation in the general ICU patients, data on SA-AKI patients are almost inexistent.

The aim of this review is to focus on the different studies comparing early versus delayed strategies in initiation of RRT in SA-AKI.

\section{Timing of Initiation of RRT}

Established and widely accepted indications for starting RRT include refractory fluid overload, severe hyperkalemia and metabolic acidosis refractory to medical therapy, signs of uremia (namely pericarditis and encephalopathy) and intoxications from dialyzable drugs or poisons [35].

There is no established universal definition for early initiation of RRT. Studies reporting different populations allocate to the "early" cohorts of patients with different serum urea levels, according to the RIFLE, AKIN or KDIGO classifications, with different urinary outputs and starting RRT within different times after AKI detection $[28,36]$. The potential benefits of earlier RRT initiation include 
premature acid-base and electrolyte equilibrium, avoidance of hypervolemia, which can be deleterious and provokes higher mortality according to different studies, elimination of uremic toxins and reducing both renal and systemic inflammation $[37,38]$. Retrospective and prospective cohorts, as well as RCTs, have proven the benefits of this approach, translated into earlier recovery of renal function, lesser hospital LOS and improved survival [36,39-41].

"Late" or "delayed" initiation RRT is also loosely defined. Most studies also report more elevated serum urea or creatinine, a higher grade of AKI classified by the RIFLE, AKIN or KDIGO classifications, lower urinary output or even only formal indications for RRT initiation as criteria for the "late" group $[28,36]$. A delayed start of RRT may allow for patient stabilization, ensuring mainly hemodynamic and ventilatory conditions, reducing potential complications associated with prompt RRT start (catheter misplacement, catheter-related bloodstream infections, bleeding or thrombotic events), and even permitting time to renal recovery averting the need for RRT [42-44]. Despite great enthusiasm for an early start of RRT, more recent RCTs and meta-analysis have questioned this approach, reporting no survival advantage $[24,25,28,45]$.

Whether these principles also apply exclusively to SA-AKI is also unknown. Table 2 summarizes the different studies that addressed early vs. late initiation of RRT in SA-AKI cohorts.

A Korean retrospective single-center study with 60 patients assessed whether a shorter interval between the start of early goal-directed therapy (EGDT) and CRRT initiation was an independent predictor of mortality in patients with SA-AKI. Patients were divided into an early $(\leq 26.4 \mathrm{~h})$ CRRT initiation group and a late $(>26.4 \mathrm{~h})$ CRRT initiation group. All-cause mortality at 28 days was significantly higher in the late CRRT group (30.0\% in the early group vs. $56.7 \%$ in the late group), even after adjusting for diabetes mellitus, liver failure, and Acute Physiology and Chronic Health Evaluation II scores, conferring a potential benefit for early initiation of CRRT [46].

Earlier, an observational retrospective single-center study with 55 SA-AKI patients at the injury or failure stages of the RIFLE classification compared outcomes between inception of early $(\leq 24 \mathrm{~h})$ and late $(>24 \mathrm{~h}$ ) continuous renal replacement therapy (CRRT). The primary outcome, 28-day mortality, was lower in the early group ( $19.4 \%$ vs. $47.4 \%$ ) but no differences were observed between the injury or failure stages [47].

A retrospective analysis of time from AKI onset to CRRT initiation was performed according to ICU mortality in 158 septic shock patients with AKI. Mortality rate was high at ICU discharge (50.6\%), and non-survivors initiated CRRT later than survivors with a cut-off time from AKI onset to CRRT initiation for ICU mortality of $16.5 \mathrm{~h}$. The cumulative mortality rate was significantly higher in patients in whom CRRT was initiated beyond $16.5 \mathrm{~h}$ after AKI onset than in those in whom CCRT was initiated within $16.5 \mathrm{~h}$, pointing to earlier initiation as a predictor of survival [48].

The definitions of "early" and "late" may also encompass other features than solely time from detection of AKI. A retrospective cohort study investigated 3-time interval parameters on the morbidity and mortality of 177 patients with septic shock-induced acute kidney injury. Time from vasopressor initiation to CRRT initiation $<24 \mathrm{~h}$, but not time from ICU admission to CRRT initiation, nor time from endotracheal intubation to CRRT initiation was associated with survival and acted as an independent factor associated with 28-day and 90-day mortality. Therefore, time from vasopressor initiation to CRRT initiation $<24 \mathrm{~h}$ could be considered as a bundle for the definition of early CRRT initiation [49]. 
Table 2. Trial summary characteristics reporting data on early vs. late renal replacement therapy initiation.

\begin{tabular}{|c|c|c|c|c|c|c|c|c|}
\hline Study & Design & $\mathbf{N}$ & RRT Modality & Early RRT Start & Late RRT Start & Follow-Up & $\begin{array}{c}\text { Mortality } \\
\text { Early vs. Late RRT Start }\end{array}$ & AUROC \\
\hline Baek, 2017 & $\begin{array}{l}\text { Retrospective, } \\
\text { single-center, } \\
\text { cohort study }\end{array}$ & 177 & CRRT & $\begin{array}{l}\text { initiation within } \\
24 \mathrm{~h} \text { of } \\
\text { vasopressor } \\
\text { treatment } \\
\text { (Tvaso-CRRT less } \\
\text { than } 24 \mathrm{~h} \text { ) }\end{array}$ & $\begin{array}{l}\text { initiation beyond } \\
24 \mathrm{~h} \text { of } \\
\text { vasopressor } \\
\text { treatment } \\
\text { (Tvaso-CRRT over } \\
24 \mathrm{~h} \text { ) }\end{array}$ & 28 days, 90 days & $\begin{array}{c}28 \text { days }-33.6 \% \text { vs. } 61.5 \%(\mathrm{p}=0.001) \\
\text { adjusted OR } 0.449(95 \% \mathrm{CI} \\
0.211-0.956), \mathrm{p}=0.038 \\
90 \text { days }-44.0 \% \text { vs. } 75.0 \%(\mathrm{p}<0.001) \\
\text { adjusted OR } 0.369(95 \% \mathrm{CI} \\
0.165-0.825), \mathrm{p}=0.015\end{array}$ & $\begin{array}{c}\text { Tvaso-CRRT > 24 } \\
\text { h, AUC, , } 6.634 \\
95 \% \text { CI } \\
0.559-0.705 \\
\text { p = 0.001; }\end{array}$ \\
\hline Barbar, 2018 & Multicenter, RCT & 488 & RRT & $\begin{array}{c}\text { RRT within } 12 \mathrm{~h} \\
\text { after } \\
\text { documentation of } \\
\text { failure-stage AKI }\end{array}$ & $\begin{array}{l}\mathrm{RRT} \text { after } 48 \mathrm{~h} \text { if } \\
\text { renal recovery had } \\
\text { not occurred }\end{array}$ & $\begin{array}{l}28 \text { days, } 90 \text { days, } \\
180 \text { days }\end{array}$ & $\begin{array}{r}28 \text { days }-45 \% \text { vs. } 42 \%(\mathrm{p}=0.48) \\
90 \text { days }-58 \% \text { vs. } 54 \%(\mathrm{p}=0.38) \\
180 \text { days }-61 \% \text { vs. } 57 \%(\mathrm{p}=0.37)\end{array}$ & - \\
\hline Carl, 2010 & $\begin{array}{l}\text { Retrospective, } \\
\text { single-center, } \\
\text { cohort study }\end{array}$ & 147 & RRT & $\begin{array}{l}\mathrm{BUN}<100 \mathrm{mg} / \mathrm{dL} \\
+ \text { AKIN stage } \geq 2\end{array}$ & $\begin{array}{l}\text { BUN } \geq 100 \mathrm{mg} / \mathrm{dL} \\
+ \text { AKIN stage } \geq 2\end{array}$ & $\begin{array}{l}14 \text { days, } 28 \text { days, } \\
365 \text { days }\end{array}$ & $\begin{array}{c}14 \text { days }-33 \% \text { vs. } 53.3 \%(\mathrm{p}=0.01) \\
\text { adjusted OR } 3.6(95 \% \text { CI } 1.7-7.6) \\
\mathrm{p}=0.001 \\
28 \text { days }-52.3 \% \text { vs. } 68.3 \%(\mathrm{p}<0.05) \\
\text { adjusted OR } 2.6(95 \% \text { CI } 1.2-5.7) \\
\mathrm{p}=0.01 \\
365 \text { days }-69.3 \% \text { vs. } 86.7 \%(\mathrm{p}<0.05) \\
\text { adjusted OR } 3.5(95 \% \text { CI } 1.2-10) \\
\mathrm{p}=0.02\end{array}$ & - \\
\hline Chon, 2012 & $\begin{array}{l}\text { Retrospective, } \\
\text { single-center, } \\
\text { cohort study }\end{array}$ & 55 & CRRT & $\begin{array}{c}\leq 24 \mathrm{~h} \text { (mean time } \\
\text { to } \\
\text { RRT }=12.5 \mathrm{~h} \text { ) } \\
\text { RIFLE-I and } \\
\text { RIFLE-F }\end{array}$ & $\begin{array}{c}>24 \mathrm{~h} \text { (mean time } \\
\text { to } \\
\text { RRT }=42.2 \mathrm{~h} \text { ) } \\
\text { RIFLE-I and } \\
\text { RIFLE-F }\end{array}$ & 28 days, 90 days & $\begin{array}{c}28 \text { days }-19.4 \% \text { vs. } 47.4 \%(p=0.030) \\
\text { adjusted HR } 3.378(95 \% \text { CI } \\
1.174-9.722), p=0.024 \\
90 \text { days }-38.2 \% \text { vs. } 61.1 \%(p=0.115)\end{array}$ & - \\
\hline Chou, 2011 & $\begin{array}{l}\text { Retrospective, } \\
\text { single-center, } \\
\text { cohort study }\end{array}$ & 370 & RRT & sRIFLE-0 or -Risk & $\begin{array}{l}\text { sRIFLE-Injury or } \\
\text {-Failure }\end{array}$ & during ICU stay & $70.8 \%$ vs. $69.7 \%, p=0.98$ & - \\
\hline Oh, 2016 & $\begin{array}{l}\text { Retrospective, } \\
\text { single-center } \\
\text { cohort study }\end{array}$ & 60 & CRRT & $\begin{array}{l}\leq 26.4 \mathrm{~h} \\
\text { mean time } \\
\text { between EGDT } \\
\text { and CRRT } \\
\text { initiation } 7.9 \mathrm{~h} \\
(1.0-25.1 \mathrm{~h})\end{array}$ & $\begin{array}{l}>26.4 \mathrm{~h} \\
\text { mean time } \\
\text { between EGDT } \\
\text { and CRRT } \\
\text { initiation } \\
61.5 \mathrm{~h} \\
(32.3-137.6 \mathrm{~h})\end{array}$ & 28 days & $\begin{array}{c}30.0 \% \text { vs. } 56.7 \%, \mathrm{p}=0.037 \\
\text { Late CRRT treatment (vs. early CRRT } \\
\text { treatment) } \\
\text { adjusted HR } 2.461(95 \% \mathrm{CI} \\
1.044-5.800), \mathrm{p}=0.040\end{array}$ & - \\
\hline
\end{tabular}


Table 2. Cont.

\begin{tabular}{|c|c|c|c|c|c|c|c|c|}
\hline Study & Design & $\mathbf{N}$ & RRT Modality & Early RRT Start & Late RRT Start & Follow-Up & $\begin{array}{c}\text { Mortality } \\
\text { Early vs. Late RRT Start }\end{array}$ & AUROC \\
\hline Payen, 2009 & $\begin{array}{l}\text { Prospective, } \\
\text { randomized, } \\
\text { multicenter study }\end{array}$ & 76 & CRRT & $\begin{array}{l}\text { RRT for at least } \\
96 \mathrm{~h} \\
\text { within } 24 \mathrm{~h} \text { of } \\
\text { randomization, }\end{array}$ & $\begin{array}{c}\text { No RRT } \\
\text { unless metabolic } \\
\text { renal failure and } \\
\text { classic } \\
\text { indications for } \\
\text { RRT } \\
\text { present }\end{array}$ & 28 days & $\begin{array}{l}\text { CRRT vs. control ( } 54 \% \text { vs. } 44 \% \text {; } \\
\qquad \mathrm{p}<0.49)\end{array}$ & - \\
\hline Shum, 2013 & $\begin{array}{l}\text { Retrospective, } \\
\text { single center, } \\
\text { cohort study }\end{array}$ & 120 & CRRT & $\begin{array}{c}\text { simplified } \\
\text { RIFLE-Risk } \\
\text { (Mean time from } \\
\text { ICU admission to } \\
\text { RRT }=20.7 \mathrm{~h} \text { ) }\end{array}$ & $\begin{array}{c}\text { simplified } \\
\text { RIFLE-Injury or } \\
\text { Failure } \\
\text { (Mean time from } \\
\text { ICU admission to } \\
\text { RRT }=10.8 \mathrm{~h} \text { ) }\end{array}$ & $\begin{array}{l}28 \text { days, } 3 \text { months } \\
\text { and } 6 \text { months }\end{array}$ & $\begin{array}{l}28 \text { days }-48.4 \% \text { vs. } 48.3 \%(p=0.994) \\
3 \text { months }-58.1 \% \text { vs. } 55.1 \%(p=0.771) \\
6 \text { months }-61.3 \% \text { vs. } 56.2 \%(p=0.62)\end{array}$ & - \\
\hline Tian, 2014 & $\begin{array}{l}\text { Retrospective, } \\
\text { single center, } \\
\text { cohort study }\end{array}$ & 160 & CRRT & CRRT group & control group & 28 days & $\begin{array}{c}\text { AKIN } 1-21.7 \% \text { vs. } 42.3 \% \text { (NS) } \\
\text { AKIN } 2-38.7 \% \text { vs. } 66.7 \%(\mathrm{p}=0.048) \\
\text { AKIN } 3-67.4 \% \text { vs. } 84.6 \% \text { (NS) } \\
\text { adjusted OR } 0.254(95 \% \text { CI } \\
0.072-0.897), p=0.033\end{array}$ & \\
\hline Yoon, 2018 & $\begin{array}{l}\text { Retrospective, } \\
\text { single center, } \\
\text { cohort study }\end{array}$ & 158 & CRRT & $<16.5 \mathrm{~h}$ & $\geq 16.5 \mathrm{~h}$ & $\begin{array}{l}28 \text { days, } 60 \text { days, } \\
90 \text { days }\end{array}$ & $\begin{array}{c}28 \text { days }-40.7 \% \text { vs. } 70.8 \% \\
\text { HR } 2.118 \text { (95\% CI 1.375-3.261), } \\
\mathrm{p}<0.001 \\
60 \text { days - HR } 2.244 \text { (95\% CI } \\
1.497-3.363), \mathrm{p}<0.001 \\
90 \text { days }- \text { HR } 2.115(95 \% \mathrm{CI} \\
1.424-3.141), \mathrm{p}<0.001 \\
\text { Interval time from AKI to CRRT } \\
\text { initiation } \\
\text { Adjusted HR } 1.016 \text { (95\% CI } \\
1.008-1.025 ; \mathrm{p}<0.001)\end{array}$ & $\begin{array}{c}\text { interval time from } \\
\text { AKI to CRRT } \\
\text { initiation for ICU } \\
\text { mortality AUC } \\
0.786 \text { ( } 95 \% \text { CI, } \\
0.716-0.856 ; \\
\text { p }<0.001 \text { ) }\end{array}$ \\
\hline
\end{tabular}

CI—confidence interval, CRRT—continuous renal replacement therapy, EGDT—early goal directed therapy, HR-hazard ratio, ICU-intensive care unit, RIFLE-Risk, Injury, Failure, Loss

of kidney function and End-stage renal disease, OR—odds ratio, RCT—randomized controlled trial, RRT—renal replacement therapy, Tvaso—time from vasopressor. 
A retrospective cohort study of 130 ICU patients with sepsis and acute renal failure requiring RRT assessed whether early implementation of RRT (defined as a BUN $<100 \mathrm{mg} / \mathrm{dL}$ ) compared to a late RRT initiation (after BUN $\geq 100 \mathrm{mg} / \mathrm{dL}$ ) had an effect on the 28-day mortality. Survival rates were $67 \%$, $47.7 \%$ and $30.7 \%$ at 14,28 and 365 days, respectively, in the early group. Survival rates were $46.7 \%$, $31.7 \%$ and $13.3 \%$, respectively, in the late group. After a logistic regression analysis, initiating dialysis with a BUN $>100 \mathrm{mg} / \mathrm{dL}$ predicted mortality at 14 days and 365 days, thus early initiation of dialysis was associated with improved survival rates up to one year [50].

A retrospective analysis of 160 critically-ill patients with SA-AKI treated with or without CRRT was performed to investigate which AKI stage might be the optimal timing for starting CRRT. Starting CRRT at AKI stage 2 was associated with reduction in the 28-day mortality, increase in the 28-day survival rate, lesser ICU LOS and a reduction in ventilation time, compared with those in the control group. This hypothesizes that AKI stage 2 may be the ideal time to initiate RRT [51].

The first RCT goes back to 2009, when twelve French ICUs conducted a RCT with 80 patients enrolled within $24 \mathrm{~h}$ of developing the first organ failure related to a new septic insult. Patients were assigned to an early intervention group, who received hemofiltration $(25 \mathrm{~mL} / \mathrm{kg} / \mathrm{h})$ for a $96-\mathrm{h}$ period, or to the conventional group, who received standard sepsis management. The primary end point (number, severity, and duration of organ failures during the 14 days) was significantly higher in the early intervention group, suggesting that early application of CRRT may be deleterious in severe sepsis and septic shock [52].

A retrospective single-center cohort study with 120 patients with septic shock and AKI evaluated the impact of early versus late initiation of CRRT on organ dysfunction. Patients were dichotomized into "early" (stage Risk of the RIFLE classification) or "late" (stages Injury or Failure of the RIFLE classification) CRRT initiation. Organ dysfunction at $48 \mathrm{~h}$, evaluated through the SOFA/non-renal SOFA, dialysis requirement and mortality at 28 days, 3 months and 6 months were similar between groups and no clinical benefits of early CRRT initiation were identified [53].

Chou and colleagues evaluated 370 septic patients presenting with AKI requiring RRT in a surgical ICU setting. Patients were divided into early (RIFLE-0 or -Risk) or late (RIFLE-Injury or -Failure) initiation of RRT by RIFLE criteria. Mortality rates in early $(70.8 \%)$ and late $(69.7 \%)$ RRT groups were similar and an early strategy was not associated to a decrease in hospital mortality. Therefore, the RIFLE classification was not able to predict the benefits of early RRT initiation in the context of septic AKI [54].

Finally, the Initiation of Dialysis Early versus Late in the Intensive Care Unit (IDEAL-ICU) was a multicenter RCT of 488 patients with septic shock and severe AKI at the failure stage of the RIFLE classification. The early group was defined as RRT start within $12 \mathrm{~h}$ of achieving the Failure stage without life-threatening AKI complications, and the delayed group started RRT after a delay of $48 \mathrm{~h}$ of achieving the Failure stage, if renal function recovery did not ensue. This trial demonstrated no significant difference in mortality between groups at 90 days [55].

\section{Limitations}

Several limitations have been pointed to the potential benefit of an early versus late strategy for RRT initiation. Results either showing advantage of an early strategy [27] or benefit from a more conservative approach [24-26] must be carefully interpreted since the ICU setting of these cohorts may be predominantly surgical $[27,56]$. Most studies include different population cohorts with clinical heterogeneities and mixed causes of AKI, in which the extrapolation of the results for SA-AKI is discouraged [24-27,57]. In addition, previous studies mostly combined early start with more-intensive dialysis and late start with less-intensive dialysis, creating a bias [13].

A recent and comprehensive meta-analysis concerning time of initiation of RRT in AKI described 18 RCTs, of which only three addressed exclusively SA-AKI cohorts and only one of these included more than 100 patients [58]. Study design, including small sample sizes, single-center and retrospective studies, paucity of double-blinded studies, heterogeneity in eligibility criteria, lack of high-quality 
studies as well as scarcity of RCTs pose major challenges in ascertaining the benefits from early versus delayed strategies [46-49,51,53].

RRT modalities (intermittent hemodialysis or CRRT) and dialysis dose have shown great disparity between studies, and were mostly left to clinicians' decision, which creates a bias concerning patients' outcomes $[46,48,49,54]$.

AKI was also subject of different definitions, and not every study included urinary output as criteria to define AKI, thus leading to exclusion of potential patients with SA-AKI [53,54]. Most studies also report the RIFLE classification for AKI, whose sensitivity for detection AKI is known to be inferior compared to contemporary KDIGO classification [53,55,59,60].

Furthermore, the definitions of "early" and "late" are not standardized and remain to be defined according to clinicians' criteria. These criteria may include time, hemodynamic parameters, biochemical characteristics, and what one study may define as "early" can be defined as "late" in other studies $[28,58,61]$. Additionally, criticism in the choice of delaying only $48 \mathrm{~h}$ to allow for renal recovery and including these patients in the "late" or "delayed" strategy has been stated. Kidney function may ensue much later than $48 \mathrm{~h}$, allowing for latter renal recovery and avert the need for RRT [55].

Follow-up length is also inconsistent and despite some studies reporting evidence of the 28-day survival benefit for the early RRT group, the effect of this strategy on long-term survival remains unclear $[47,49,61]$. Moreover, the benefit of RRT might be attributable not only to the early nonspecific removal of inflammatory mediators but also to an early stabilization of the hemodynamic, respiratory, and biological status [46].

\section{Future Perspectives}

The optimal timing for initiation of RRT is not clarified on the basis of research evaluated to date both in SA-AKI and other etiologies of AKI [28,58,61]. The results of the studies included in our analysis are contradictory. Large, multicenter prospective observational studies are required to make sure the impact of CRRT timing on septic AKI [62].

To our knowledge, no specific RCT is underway to ascertain the optimal time for RRT initiation in SA-AKI. The Standard Versus Accelerated Initiation of Dialysis in Acute Kidney Injury (STARRT-AKI) is an ongoing multicenter trial that plans to enroll at least 2866 critically ill patients in order to detect a $6 \%$ difference in mortality in favor of an early RRT start strategy. A specific subgroup analysis for patients with sepsis and septic shock, as defined by the Sepsis-3 criteria based on the rationale that earlier RRT, due to more aggressive removal of inflammatory mediators, might have a more prominent effect among patients with SA-AKI, is awaited in order to define whether an early strategy could be beneficial for this specific population [63].

All in all, timing to start RRT should be individualized to patients' clinical status and laboratory progression. Nonetheless, an early RRT start in septic patients could potentially improve outcomes by limiting systemic inflammation, fluid overload and organ injury, though consistent evidence is still lacking. Moreover, SA-AKI is associated with lower SCr due to reduced production of creatinine and hemodilution associated with a considerably positive fluid balance, and a more pronounced oliguria, thus a less severe KDIGO stage defined these criteria might underestimate the severity of AKI and create a bias in defining RRT timing. Novel biomarkers, such as NGAL and TIMP-2 x IGFBP-7, have been reported as potential predictors of AKI severity after admission, which might prove useful in deciding the timing to start RRT in this setting, though further studies are still required to validate the routine use of these biomarkers in clinical practice.

\section{Conclusions}

In conclusion, the available evidence demonstrates contradictory results concerning the benefits of early RRT initiation in SA-AKI. Moreover, postponing RRT initiation may allow for renal recovery from AKI, averting the need for RRT. Evidence results essentially from small, retrospective, non-double blinded studies and although evidence in mortality improvement is lacking, especially with RCTs, 
other outcomes such as ICU and hospital LOS, development of CKD and late mortality were rarely assessed. Definitions for "early" and "late" start need to be standardized and the optimal time to initiate RRT remains undefined. Large multicenter randomized trials with better design are needed to answer these questions.

Author Contributions: J.A.F. and J.G. made substantial contributions to the study concept and design, analysis and interpretation of data. J.A.F., J.G. and F.M. were involved in drafting the manuscript and revising it critically for important intellectual content. J.A.F. and F.M. participated in the acquisition of data. J.G. and J.A.L. were involved in the critical revision of the manuscript and approval of the final version to be submitted. All authors have read and agreed to the published version of the manuscript.

Conflicts of Interest: The authors declare no conflicts of interest.

\section{References}

1. Chertow, G.; Burdick, E.; Honour, M.; Bonventre, J.; Bates, D. Acute kidney injury, mortality, length of stay, and costs in hospitalized patients. J. Am. Soc. Nephrol. 2005, 16, 3365-3370. [CrossRef]

2. Kellum, J.A.; Prowle, J.R. Paradigms of acute kidney injury in the intensive care setting. Nat. Rev. Nephrol. 2018, 14, 217-230. [CrossRef] [PubMed]

3. Uchino, S.; Kellum, J.A.; Bellomo, R.; Doig, G.S.; Morimatsu, H.; Morgera, S. Acute renal failure in critically ill patients: A multinational, multicenter study. JAMA 2005, 294, 813-818. [CrossRef] [PubMed]

4. Hoste, E.A.; Bagshaw, S.M.; Bellomo, R.; Cely, C.M.; Colman, R.; Cruz, D.N.; Honoré, P. Epidemiology of acute kidney injury in critically ill patients: The multinational AKI-EPI study. Intensive Care Med. 2015, 41, 1411-1423. [CrossRef] [PubMed]

5. Bellomo, R. The epidemiology of acute renal failure: 1975 versus 2005. Curr. Opin. Crit. Care 2006, 12, 557-560. [CrossRef]

6. Lafrance, J.P.; Miller, D.R. Acute kidney injury associates with increased long-term mortality. J. Am. Soc. Nephrol. 2010, 21, 345-352. [CrossRef]

7. Thongprayoon, C.; Kaewput, W.; Thamcharoen, N.; Bathini, T.; Watthanasuntorn, K.; Lertjitbanjong, P.; Kröner, P.T. Incidence and Impact of Acute Kidney Injury after Liver Transplantation: A Meta-Analysis. J. Clin. Med. 2019, 8, 372. [CrossRef]

8. Lertjitbanjong, P.; Thongprayoon, C.; Cheungpasitporn, W.; O'Corragain, O.A.; Srivali, N.; Bathini, T.; Watthanasuntorn, K.; Aeddula, N.R.; Salim, S.A.; Ungprasert, P.; et al. Acute Kidney Injury after Lung Transplantation: A Systematic Review and Meta-Analysis. J. Clin. Med. 2019, 8, 1713. [CrossRef]

9. Thongprayoon, C.; Kaewput, W.; Thamcharoen, N.; Bathini, T.; Watthanasuntorn, K.; Salim, S.A.; Ungprasert, P.; Lertjitbanjong, P.; Aeddula, N.R.; Torres-Ortiz, A.; et al. Acute Kidney Injury in Patients Undergoing Total Hip Arthroplasty: A Systematic Review and Meta-Analysis. J. Clin. Med. 2019, 8, 66. [CrossRef]

10. Bellomo, R.; Ronco, C.; Kellum, J.A.; Mehta, R.L.; Palevsky, P. Acute renal failure-definition, outcome measures, animal models, fluid therapy and information technology needs: The Second International Consensus Conference of the Acute Dialysis Quality Initiative (ADQI) Group. Crit. Care 2004, 8, R204-R212. [CrossRef]

11. Lassnigg, A.; Schmidlin, D.; Mouhieddine, M.; Bachmann, L.M.; Druml, W.; Bauer, P.; Hiesmayr, M. Minimal changes of serum creatinine predict prognosis in patients after cardiothoracic surgery: A prospective cohort study. J. Am. Soc. Nephrol. 2004, 15, 1597-1605. [CrossRef] [PubMed]

12. Mehta, R.L.; Kellum, J.A.; Shah, S.V.; Molitoris, B.A.; Ronco, C.; Warnock, D.G.; Levin, A. Acute Kidney Injury Network: Report of an initiative to improve outcomes in acute kidney injury. Crit. Care 2007, 11, R31. [CrossRef] [PubMed]

13. Kidney Disease: Improving Global Outcomes (KDIGO) Acute Kidney Injury Work Group. KDIGO clinical practice guideline for acute kidney injury. Kidney Int. Suppl. 2012, 2, S1-S138.

14. Chawla, L.S.; Bellomo, R.; Bihorac, A.; Goldstein, S.L.; Siew, E.D.; Bagshaw, S.M.; Bittleman, D.; Cruz, D.; Endre, Z.; Fitzgerald, S.L.; et al. Acute kidney disease and renal recovery: Consensus report of the Acute Disease Quality Initiative (ADQI) 16 Workgroup. Nat. Rev. Nephrol. Nat. Res. 2017, 13, 241-257. [CrossRef] [PubMed] 
15. Murugan, R.; Kellum, J.A. Acute kidney injury: What's the prognosis? Nat. Rev. Nephrol. 2011, 7, $209-217$. [CrossRef]

16. Doyle, J.F.; Forni, L.G. Acute kidney injury: Short-term and long-term effects. Crit. Care 2016, $20,188$. [CrossRef]

17. Bellomo, R.; Cass, A.; Cole, L.; Finfer, S.; Gallagher, M.; Lee, J.; Lo, S.; McArthur, C.; McGuiness, S.; Norton, R.; et al. An observational study fluid balance and patient outcomes in the Randomized Evaluation of Normal vs. Augmented Level of Replacement Therapy trial. Crit. Care Med. 2012, 40, 1753-1760.

18. Payen, D.; de Pont, A.C.; Sakr, Y.; Spies, C.; Reinhart, K.; Vincent, J.L. A positive fluid balance is associated with a worse outcome in patients with acute renal failure. Crit. Care 2008, 12, R74. [CrossRef]

19. Bouchard, J.; Soroko, S.B.; Chertow, G.M.; Himmelfarb, J.; Ikizler, T.A.; Paganini, E.P.; Mehta, R.L. Fluid accumulation, survival and recovery of kidney function in critically ill patients with AKI. Kidney Int. 2009, 76, 422-427. [CrossRef]

20. Davison, D.; Junker, C. Advances in critical care for the nephrologist: Hemodynamic monitoring and volume management. Clin. J. Am. Soc. Nephrol. 2008, 3, 554-561. [CrossRef]

21. Finfer, S.; Chittock, D.R.; Su, S.Y.; Blair, D.; Foster, D.; Dhingra, V.; Bellomo, R.; Cook, D.; Dodek, P.; Henderson, W.R.; et al. Intensive versus conventional glucose control in critically ill patients. N. Engl. J. Med. 2009, 360, 1283-1297. [PubMed]

22. Boccardo, P.; Remuzzi, G.; Galbusera, M. Platelet dysfunction in renal failure. Semin. Thromb. Hemost. 2004, 30, 579-589. [CrossRef] [PubMed]

23. Vanmassenhove, J.; Kielstein, J.; Joerres, A.; Biesen, W.V. Management of patients at risk of AKI. Lancet 2017, 389, 2139-2151. [CrossRef]

24. Wald, R.; Adhikari, N.K.; Smith, O.M.; Weir, M.A.; Pope, K.; Cohen, A.; Thorpe, K.; McIntyre, L.; Lamontagne, F.; Soth, M.; et al. Comparison of standard and accelerated initiation of renal replacement therapy in acute kidney injury. Kidney Int. 2015, 88, 897-904. [CrossRef] [PubMed]

25. Jamale, T.E.; Hase, N.K.; Kulkarni, M.; Pradeep, K.J.; Keskar, V.; Jawale, S.; Mahajan, D. Earlier-start versus usual-start dialysis in patients with community-acquired acute kidney injury: A randomized controlled trial. Am. J. Kidney Dis. 2013, 62, 1116-1121. [CrossRef] [PubMed]

26. Gaudry, S.; Hajage, D.; Schortgen, F.; Martin-Lefevre, L.; Pons, B.; Boulet, E.; Boyer, A.; Chevrel, G.; Lerolle, N.; Carpentier, D.; et al. Initiation Strategies for Renal-Replacement Therapy in the Intensive Care Unit. N. Engl. J. Med. 2016, 375, 122. [CrossRef]

27. Zarbock, A.; Kellum, J.A.; Schmidt, C.; Van Aken, H.; Wempe, C.; Pavenstädt, H.; Boanta, A.; Gerß, J.; Meersch, M. Effect of Early vs. Delayed Initiation of Renal Replacement Therapy on Mortality in Critically Ill Patients With Acute Kidney Injury: The ELAIN Randomized Clinical Trial. JAMA 2016, 315, 2190. [CrossRef]

28. Wierstra, B.T.; Kadri, S.; Alomar, S.; Burbano, X.; Barrisford, G.W.; Kao, R.L.C. The impact of "early" versus "late" initiation of renal replacement therapy in critical care patients with acute kidney injury: A systematic review and evidence synthesis. Crit. Care 2016, 20, 122. [CrossRef]

29. Besen, B.A.M.P.; Romano, T.G.; Mendes, P.V.; Gallo, C.A.; Zampieri, F.G.; Nassar, A.P., Jr.; Park, M. Early Versus Late Initiation of Renal Replacement Therapy in Critically Ill Patients: Systematic Review and Meta-Analysis. J. Intensive Care Med. 2019, 34, 714. [CrossRef]

30. Bagshaw, S.M.; Uchino, S.; Bellomo, R.; Morimatsu, H.; Morgera, S.; Schetz, M.; Tan, I.; Bouman, C.; Macedo, E.; Gibney, M.; et al. Septic acute kidney injury in critically ill patients: Clinical characteristics and outcomes. Clin. J. Am. Soc. Nephrol. 2007, 2, 431-439. [CrossRef]

31. Cruz, M.G.; Dantas, J.G.; Levi, T.M.; Rocha, M.; de Souza, S.P.; Boa-Sorte, N.; de Moura, C.G.; Cruz, C.M. Septic versus non-septic acute kidney injury in critically ill patients: Characteristics and clinical outcomes. Rev. Bras Ter. Intensiva. 2014, 26, 384-391. [CrossRef] [PubMed]

32. Prowle, J.R.; Bellomo, R. Sepsis-associated acute kidney injury: Macrohemodynamic and microhemodynamic alterations in the renal circulation. Semin. Nephrol. 2015, 35, 64-74. [CrossRef] [PubMed]

33. Poston, J.T.; Koyner, J.L. Sepsis associated acute kidney injury. BMJ 2019, 364, k4891. [CrossRef] [PubMed]

34. Gomez, H.; Ince, C.; De Backer, D.; Pickkers, P.; Payen, D.; Hotchkiss, J.; Kellum, J.A. A unified theory of sepsis- induced acute kidney injury: Inflammation, microcirculatory dysfunction, bioenergetics, and the tubular cell adaptation to injury. Shock 2014, 41, 3-11. [CrossRef]

35. Pannu, N.; Gibney, R.N. Renal replacement therapy in the intensive care unit. Ther. Clin. Risk Manag. 2005, 1, 141-150. [CrossRef] 
36. Karvellas, C.J.; Farhat, M.R.; Sajjad, I.; Mogensen, S.S.; Leung, A.A.; Wald, R.; Bagshaw, S.M. A comparison of early versus late initiation of renal replacement therapy in critically ill patients with acute kidney injury: A systematic review and meta-analysis. Crit. Care 2011, 15, R72. [CrossRef]

37. Matson, J.; Zydney, A.; Honore, P.M. Blood filtration: New opportunities and the implications of systems biology. Crit. Care Resusc. 2004, 6, 209-217.

38. Sugahara, S.; Suzuki, H. Early start on continuous hemodialysis therapy improves survival rate in patients with acute renal failure following coronary bypass surgery. Hemodial Int. 2004, 8, 320-325. [CrossRef]

39. Bagshaw, S.M.; Uchino, S.; Bellomo, R.; Morimatsu, H.; Morgera, S.; Schetz, M.; Tan, I.; Bouman, C.; Macedo, E.; Gibney, M.; et al. Timing of renal replacement therapy and clinical outcomes in critically ill patients with severe acute kidney injury. J. Crit. Care 2009, 24, 129-140. [CrossRef]

40. Liu, K.D.; Himmelfarb, J.; Paganini, E.; Ikizler, T.A.; Soroko, S.H.; Mehta, R.L.; Chertow, G.M. Timing of initiation of dialysis in critically ill patients with acute kidney injury. Clin. J. Am. Soc. Nephrol. 2006, 1, 915-919. [CrossRef]

41. Leite, T.T.; Macedo, E.; Pereira, S.M.; Bandeira, S.R.; Pontes, P.H.; Garcia, A.S.; Militão, F.R.; Sobrinho, I.M.; Assunção, L.M.; Libório, A.B. Timing of renal replacement therapy initiation by AKIN classification system. Crit. Care 2013, 17, R62. [CrossRef] [PubMed]

42. Shingarev, R.; Wille, K.; Tolwani, A. Management of complications in renal replacement therapy. Semin. Dial 2011, 24, 164-168. [CrossRef] [PubMed]

43. Moreira, F.T.; Palomba, H.; Chaves, R.C.F.; Bouman, C.; Schultz, M.J.; Serpa Neto, A. Early versus delayed initiation of renal replacement therapy for acute kidney injury: An updated systematic review, meta-analysis, meta-regression and trial sequential analysis of randomized controlled trials. Rev. Bras Ter. Intensiva 2018, 30, 376-384. [CrossRef] [PubMed]

44. Elseviers, M.M.; Lins, R.L.; Van der Niepen, P.; Hoste, E.; Malbrain, M.L.; Damas, P.; Devriendt, J. Renal replacement therapy is an independent risk factor for mortality in critically ill patients with acute kidney injury. Crit. Care 2010, 14, R221. [CrossRef]

45. Combes, A.; Brechot, N.; Amour, J.; Cozic, N.; Lebreton, G.; Guidon, C.; Zogheib, E.; Thiranos, J.C.; Rigal, J.C.; Bastien, O.; et al. Early high-volume hemofiltration versus standard care for post-cardiac surgery shock. The HEROICS study. Am. J. Respir. Crit. Care Med. 2015, 192, 1179-1190. [CrossRef]

46. Oh, H.J.; Kim, M.H.; Ahn, J.Y.; Ku, N.S.; Park, J.T.; Han, S.H.; Choi, J.Y.; Han, S.H.; Yoo, T.H.; Song, Y.G.; et al. Can early initiation of continuous renal replacement therapy improve patient survival with septic acute kidney injury when enrolled in early goal-directed therapy? J. Crit. Care 2016, 35, 51-56. [CrossRef]

47. Chon, G.R.; Chang, J.W.; Huh, J.W.; Lim, C.M.; Koh, Y.; Park, S.K.; Park, J.S.; Hong, S.B. A comparison of the time from sepsis to inception of continuous renal replacement therapy versus RIFLE criteria in patients with septic acute kidney injury. Shock 2012, 38, 30-36. [CrossRef]

48. Yoon, B.R.; Leem, A.Y.; Park, M.S.; Kim, Y.S.; Chung, K.S. Optimal timing of initiating continuous renal replacement therapy in septic shock patients with acute kidney injury. Sci. Rep. 2019, 9, 11981. [CrossRef]

49. Baek, S.D.; Yu, H.; Shin, S.; Park, H.S.; Kim, M.S.; Kim, S.M.; Lee, E.K.; Chang, J.W. Early continuous renal replacement therapy in septic acute kidney injury could be defined by its initiation within $24 \mathrm{~h}$ of vasopressor infusion. J. Crit. Care 2017, 39, 108-114. [CrossRef]

50. Carl, D.E.; Grossman, C.; Behnke, M.; Sessler, C.N.; Gehr, T.W. Effect of timing of dialysis on mortality in critically ill, septic patients with acute renal failure. Hemodial Int. 2010, 14, 11-17. [CrossRef]

51. Tian, H.; Sun, T.; Hao, D.; Wang, T.; Li, Z.; Han, S.; Qi, Z.; Dong, Z.; Lv, C.; Wang, X. The optimal timing of continuous renal replacement therapy for patients with sepsis-induced acute kidney injury. Int. Urol. Nephrol. 2014, 46, 2009-2014. [CrossRef] [PubMed]

52. Payen, D.; Mateo, J.; Cavaillon, J.M.; Fraisse, F.; Floriot, C.; Vicaut, E. Impact of continuous venovenous hemofiltration on organ failure during the early phase of severe sepsis: A randomized controlled trial. Crit. Care Med. 2009, 37, 803-810. [CrossRef] [PubMed]

53. Shum, H.P.; Chan, K.C.; Kwan, M.C.; Yeung AW, T.; Cheung EW, S.; Yan, W.W. Timing for initiation of continuous renal replacement therapy in patients with septic shock and acute kidney injury. Ther. Apher. Dial. 2013, 17, 305-310. [CrossRef] [PubMed]

54. Chou, Y.H.; Huang, T.M.; Wu, V.C.; Wang, C.Y.; Shiao, C.C.; Lai, C.F.; Tsai, H.B.; Chao, C.T.; Young, G.H.; Wang, W.J.; et al. Impact of timing of renal replacement therapy initiation on outcome of septic acute kidney injury. Crit. Care 2011, 15, R134. [CrossRef] 
55. Barbar, S.D.; Clere-Jehl, R.; Bourredjem, A.; Hernu, R.; Montini, F.; Bruyère, R.; Lebert, C.; Bohé, J.; Badie, J.; Eraldi, J.P.; et al. Investigators I-IT, the CTN. Timing of renal-replacement therapy in patients with acute kidney injury and sepsis. N. Engl. J. Med. 2018, 379, 1431-1442. [CrossRef]

56. Bouman, C.S.; Oudemans-Van Straaten, H.M.; Tijssen, J.G.; Zandstra, D.F.; Kesecioglu, J. Effects of early high-volume continuous venovenous hemofiltration on survival and recovery of renal function in intensive care patients with acute renal failure: A prospective, randomized trial. Crit. Care Med. 2002, 30, 2205-2211. [CrossRef]

57. Lim, C.C.; Tan, C.S.; Kaushik, M.; Tan, H.K. Initiating acute dialysis at earlier Acute Kidney Injury Network stage in critically ill patients without traditional indications does not improve outcome: A prospective cohort study. Nephrology (Carlton) 2015, 20, 148-154. [CrossRef]

58. Zhang, L.; Chen, D.; Tang, X.; Li, P.; Zhang, Y.; Tao, Y. Timing of initiation of renal replacement therapy in acute kidney injury: An updated meta-analysis of randomized controlled trials. Ren Fail. 2020, 42, 77-88. [CrossRef]

59. Lopes, J.A.; Jorge, S. The RIFLE and AKIN classifications for acute kidney injury: A critical and comprehensive review. Clin. Kidney J. 2013, 6, 8-14. [CrossRef]

60. Luo, X.; Jiang, L.; Du, B.; Wen, Y.; Wang, M.; Xi, X. A comparison of different diagnostic criteria of acute kidney injury in critically ill patients. Crit. Care 2014, 18, R144. [CrossRef]

61. Xiao, L.; Jia, L.; Li, R.; Zhang, Y.; Ji, H.; Faramand, A. Early versus late initiation of renal replacement therapy for acute kidney injury in critically ill patients: A systematic review and meta-analysis. PLoS ONE 2019, 14, e0223493. [CrossRef] [PubMed]

62. Li, Y.; Li, H.; Zhang, D. Timing of continuous renal replacement therapy in patients with septic AKI: A systematic review and meta-analysis. Medicine (Baltimore) 2019, 98, e16800. [CrossRef] [PubMed]

63. STARRT-AKI Investigators. STandard versus Accelerated initiation of Renal Replacement Therapy in Acute Kidney Injury: Study Protocol for a Multi-National, Multi-Center, Randomized Controlled Trial. Can. J. Kidney Health Dis. 2019, 6, 2054358119852937.

(C) 2020 by the authors. Licensee MDPI, Basel, Switzerland. This article is an open access article distributed under the terms and conditions of the Creative Commons Attribution (CC BY) license (http://creativecommons.org/licenses/by/4.0/). 